\title{
Concept of body and sexuality in Native American novels
}

\author{
V. Bazova
}

National Aviation University Kyiv, Ukraine

Corresponding author. E-mail: Lakshmi11@i.ua

Paper received 31.03.19; Accepted for publication 10.04.19.

\author{
https://doi.org/10.31174/SEND-Ph2019-194VII58-01
}

\begin{abstract}
The article analyzes various options for interpreting of the concept of corporeality in the works of such prominent Native American writers as N. Scott Momaday, Leslie Marmon Silko, Ignatia Broker. The essence of the "corporality" concept is revealed, scientific developments from the mentioned problems are analyzed. Gender relations and colonialism is not a new issue in modern literary criticism, since the conquered territories in the minds of the conquerors are partly represented by the body of a conquered woman. The institutionalization of the patriarchy as a system of social control and social order in colonial studies is transformed from a low level of familyformations into the highest levels of society and is reflected in the whole system of social relations. Indian body, as a rather exotic corporeality, plays an important role in this case. Having studied the specifics of the concept corporeality use in the novels of these writers, it can be argued that this concept is divided into two components - the "body" itself, as a physical object in space, and the perception of this body, which is a manifestation of the universal "corporeality" with the perception of gender roles and sexuality in the context of the Indian cultural tradition.
\end{abstract}

Keywords: N. Scott Momaday, Leslie Marmon Silko, Ignatia Broker, corporeality, body, Native Americans.

Introduction. Nowadays there is no doubt that the processes of decolonization play aleading role in shaping the literary tradition of the North American indigenous nations. Indian writers like N. Scott Momaday, Ignatia Broker and Leslie Marmon Silko declare their works as ideologically intertwined with the claims for the national identity of the colonized peoples of North America, referring to the national indigenous heritage that has long been considered an unimportant dying cultural component of the American Indians. An important role in this heritage is played by the concept of corporeality and sexuality. Literary-physical discourse as a value-ideological segment of the picture of the world of these authors is a special way of promoting the author's consciousness in the artistic text. O.Shostak remarked that "the notion of sex and sexuality in indigenous communities in North America was significantly different from those of their Spanish, French and English conquerors. Many indigenous societies distinguished between the third and fourth sexes, which defined the roles of those community members whose gender identity did not coincide with the natural sex. For example, among Zuni people, gender was considered to be a "gained, not innate, feature." The biological sex did not dictate those roles that people chose " $[5$, p.35].

It must be admitted that in the contemporary cultural discourse of American Indians we are dealing with a huge number of varied definitions of physicality and sexuality, which today constitute one of the key system-forming concepts of cultural, sociological, linguistic, anthropological and literary aspects of the study of the North American indigenous people. "As an anthropologist Will Rosco convinces, alternative gender was one of the most common features of many societies in the North American pre-Columbian continent. The memoirs of the Europeans contained information about the presence of this phenomenon in 155 nations of North America, although it was not mandatory that this phenomenon could be observed in every nation. Sue-Helen Jacobs and Jason Cromwell argue that "gender variations" could be observed in all regions of the continent, they "crossed the geographical, national and linguistic borders", anthropologists speak of "the cultural expression of parallel genders (of which there are more than two) and the opportunity to change gender roles throughout life "[5, p.35]. Together with the usual gender roles - a man and a woman, these peoples often observed the third species - berdaches.

Analysis of recent publications. The problem of the concept of corporeality and its influence on literary works were researched by such scholars as K.Millet, P.G.Allen, O.Homilko, Z.Borisyuk, N.Vysotsk, M.Kolesnik, V.Rozin, O.Shostak.

The study of the corporeality in the works of indigenous writers through the prism of narratology and receptive aesthetics can reveal the author's intentionality and dimensions of the reader's reception, as well as it helps to rethink the fundamental modes of human existence of the indigenous peoples of North America, which determines the aim of this research.

The purpose of the article is to identify and analyze ways of verbalization of the corporeality concept in the Indian fiction. Our goal is to fulfill the following tasks: to find out the essence of the concept of "corporeality" in the literature of indigenous American writers, to identify the most representative writers working in this direction.

Presentation of the main research material. Studying the specifics of the corporeality concept in Indian literature, one can determine that the very idea of corporeality is "not literally the human body in its organic representation, but sensuality as its main ontological property. Outside the sensuality of physicality does not exist. Therefore, the reality that presents sensually in this world can be called the notion of physicality "[1, p.73]. In our opinion, in contemporary Indian literature, one should define a special attitude towards the body and its functions. It is already an instrument of comprehension of the surrounding universe and sensual pleasure, but rather a peculiar sign of reading, interpreting and genetically deciphering the mysteries of the universe. "The diversity of gender roles is reflected in the cosmogony of indigenous peoples, and the public decay of these complex gender relationships is associated with violent assimilation and disdainful attitude of the colonialists to indigenous traditions. As a result of the physical and psychological pressure from settlers, practices that once were an integral part of life, transformed into somewhat less visible, but they 
still came to us through various signs. Each nation has its own name for gender-varying roles, while anthropologists continue to use the historically-used term "Berdache", which has a European connotation of sexual deviations from the norm "[5, p.39].

As O.Shostak emphasizes, "gender relations and colonialism are not new in modern literary criticism, because conquered territories in the minds of the conquerors are partly represented by the body of a conquered body. The institutionalization of the patriarchy as a system of social control and social order in colonial studies is transformed from a low-lying family to the highest levels of society and is reflected in the whole system of social relations "[3, p.201]. Indian corporeality, as a rather exotic body, plays an important role in this case. An example of this can serve Angela, the heroine of the novel "House Made of Dawn" by N. Scott Momaday, who as a pregnant woman aspires to entertain with the Indian Abel. From the very first minutes of her acquaintance, she embraced the desire to subjugate his will and to seduce him.

"He looked at her without the trace of a smile, but his voice was soft and genial, steady. He would give her no clear way to be contemptuous of him. $<\ldots>$ It offended her that he would not buy and sell. Still, she knew how to learn at her own expense, and eventually she would make good the least investment of her pride. $<\ldots>$ She was full of irritation. She knew only how to persist, but she had already begun to sense that it was no use: and that made her seethe. $<\ldots>$ His reserve was too much for her. She would have liked to throw him off balance, to startle and appall him, to make an obscene gesture, perhaps, or to say, "How would you like a white woman? My white belly and my breasts, my painted fingers and my feet?" [8;c.33-34].

However, this confrontation does not lead to the expected triumph of white body, rather the opposite - the heroine feels immediate disgust toward her own physicality, which in general is inherent in representatives of patriarchal cultures, where femininity was considered lower than masculinity.

"She thought of her body and could not understand that it was beautiful. She could think of nothing more vile and obscene than the raw flesh and blood of her body, the raveled veins and the gore upon of her bones. And now the monstrous fetal form, the blue, great-headed thing growing within and feeding upon her. From the time she was a child and first saw her own blood, how it brimmed in a cut on the back of her hand, she had conceived a fear and disgust of her body which nothing could make her forget. She did not fear death, only the body's implication in it. And at odd moments she wished with all her heart to die by fire of such intense heat that her body should dissolve in it all at once" [8, c.34].

The change in the heroine's value points takes place on the stage of intimate relationships between Angela and Abel. Angela is shocked that her desire to have fun came back against her. "She had not foreseen this turn of tables and events, had not imagined that he could turn her scheme around. $\langle\ldots\rangle$ Before her now was the strange reality of her shame and the tyranny of light that lay upon it. He was dark and massive above her, poised and tinged with pale blue light. And in that split second she thought again of the badger at the water, and the great bear, blueblack and blowing" [8, c.62-64].

In Leslie Marmon Silko's novel "Gardens in the Dunes" the question was raised about the essence of the true sexuality and its value for the ancient peoples of the North American continent. Speaking about Sister Salt (one of the two protagonists of the novel), her friends stated that "she was like people in the old days ... before the missionaries came. In those days, the Chejuhites really knew how to enjoy each other, and only Sand Lizards could enjoy sex more than them. And it was true: Sister Salt had sex as she did all before the arrival of the missionaries "[10, c.206]. Perhaps it is this, far from Christianity, attitude towards the body and sexuality made it possible for the Indians to survive.

Body as a part of the earth is represented in the novel by Ignatia Broker "Woman of the Night Flight". Speaking about the modern living conditions that the Ojibwe people have to get used to, Ouna (Woman of the Night Flight) speaks of their physical presence in the modern world:

" My children and grandchildren are doing well in the way of the white strangers. They are farmers, they are teachers, and they work in the factories that make the many new tools - even the airplanes that crowd the birds from the sky. And they are with honor, for they have fought in the white man's wars. Because of this, part of my dust lies in the foreign lands. My mother said to me that our dust cannot be erased from the earth of our land. Let this be true also for my children who lie in the foreign lands, for I have buried the drums that were a part of their lives" [6, c.130].

Conclusions. Summarizing the written above, it can be argued that in the works of Native American writers, the concept of "corporeality" is divided into two components - the actual "body" as a physical object in space, and the perception of this body, which is a manifestation of universal "physicality" which is related with the perception of gender roles and sexuality in the context of the Indian cultural tradition. Usually a description of the body's condition is the equivalent of human feelings in the romance tradition of indigenous writers.

\section{REFERENCES}

1. Гомілко О. Феномен тілесності: дис. ... докт. філософ. наук: спец. 09.00.04 «Філософська антропологія, філософія культури»/ О.Гомілко. - К., 2007. - 438с.

2. Шостак О. Втілення ідеї всеєдності у романі «Сади в дюнах» Леслі Мармон Сілко/ О.Шостак// Гуманітарна освіта в технічних вищих навчальних закладах: зб.наук.праць. - К.: Університет «Україна», 2013. Вип.28. - С.295-311.

3. Шостак О. Кохання як імперський захват (на прикладі романів Н.Скотта Момадея «Дім створений із світанку»

та «Трьохденний шлях» Джозефа Бойдена) / О.Шостак// Гуманітарна освіта в технічних вищих навчальних закладах: зб.наук.праць. - К.: Університет «Україна», 2015. Вип.32. - С.201-217.

4. Шостак О. Вчення про священне коло як шлях до подолання національного травматичного синдрому у творчості американських та канадських письменників індіанського походження/ О.Шостак// Сучасні літературознавчі студії. Літературний дискурс: транс культурні виміри: зб.наук.праць. - К.:Вид. центр КНЛУ,2015. - С.613-623. 
5. Шостак О. Гендерна ідентичність корінних жителів Північної Америки/ О.Шостак// Наукові записки Національного університету «Острозька академія». Серія «Культурологія». Проблеми культурної ідентичності в ситуації сучасного діалогу культур: матеріали $\mathrm{X}$ міжнародної наукової конференції. (Острог, 18-19 травня 2017 року). Острог : Видавництво Національного університету «Острозька академія», 2018. - Вип. 19. - С.34-51.

6. Broker, Ignatia. Night Flying Woman. An Ojibway Narrative / Ignatia Broker. - St.Paul: Borealis Books, 1983. - $135 \mathrm{p}$
7. Millett, K. Sexual Politics / K. Millett. - Garden City, NY: Doubleday Press, 1970. - 397p.

8. Momaday, N.Scott. The House Made of Dawn :[novel] / N. Scott Momadey. - N.Y.: Harper\&Row, 1968. - 212 p.

9. Silko, Leslie Marmon. Almanac of the Dead :[novel] / Leslie Marmon Silko. - N.Y.: Simon and Schuster, 1991. - 763p.

10. Silko, Leslie Marmon Gardens in the Dunes/Leslie Marmon Silko. - Scribner Paperback Fiction Published by Simon and Schuster, 1999. $-480 \mathrm{p}$.

\section{REFERENCES}

1. Homilko O. Fenomen tilesnosti: dys. ... dokt. filosof. nauk: spets. 09.00.04 «Filosofs'ka antropolohiya, filosofiya kul'tury»//O.Homilko. - K., 2007. - 438s.

2. Shostak O. Vtilennya ideyi vseyednosti u romani «Sady v dyunakh» Lesli Marmon Silko/ O.Shostak// Humanitarna osvita $\mathrm{v}$ tekhnichnykh vyshchykh navchal'nykh zakladakh: zb.nauk.prats'. - K.: Universytet «Ukrayina», 2013. Vyp.28. - S.295-311.

3. Shostak O. Kokhannya yak impers'kyy zakhvat (na prykladi romaniv N.Skotta Momadeya «Dim stvorenyy iz svitanku» ta «Tr'okhdennyy shlyakh» Dzhozefa Boydena) / O.Shostak// Humanitarna osvita $\mathrm{v}$ tekhnichnykh vyshchykh navchal'nykh zakladakh: zb.nauk.prats'. - K.: Universytet «Ukrayina», 2015. - Vyp.32. - S.201-217.

4. Shostak O. Vchennya pro svyashchenne kolo yak shlyakh do podolannya natsional'noho travmatychnoho syndromu u tvorchosti amerykans'kykh ta kanads'kykh pys'mennykiv indians'koho pokhodzhennya/ O.Shostak// Suchasni literaturoznavchi studiyi. Literaturnyy dyskurs: trans kul'turni vymiry: zb.nauk.prats'. - K.:Vyd. tsentr KNLU,2015. - S.613-623.

5. Shostak O. Henderna identychnist' korinnykh zhyteliv Pivnichnoyi Ameryky/ O.Shostak// Naukovi zapysky Natsional'noho universytetu «Ostroz'ka akademiya». Seriya «Kul'turolohiya». Problemy kul'turnoyi identychnosti v sytuatsiyi suchasnoho dialohu kul'tur: materialy X mizhnarodnoyi naukovoyi konferentsiyi. (Ostroh, 18-19 travnya 2017 roku). - Ostroh : Vydavnytstvo Natsional'noho universytetu «Ostroz'ka akademiya», 2018. - Vyp. 19. - S.34-51. 